\title{
Fabryki wyrobów tytoniowych w Bydgoszczy w drugiej połowie XIX wieku do ustanowienia Polskiego Monopolu Tytoniowego w 1922 roku
}

\begin{abstract}
Abstrakt: Celem artykułu jest prześledzenie historii przemysłu tytoniowego w Bydgoszczy od połowy XIX w. do momentu ustanowienia w 1922 r. Polskiego Monopolu Tytoniowego. W badaniach korzystano z Akt Rejestru Handlowego, Akt miasta Bydgoszczy i Akt budowlanych miasta Bydgoszczy z lat 1850-1925. Informacje archiwalne uzupełniono o dane z prasy codziennej z okresu 1908-1924. Temat ukazano na tle sytuacji politycznej i gospodarczej miasta (do $1920 \mathrm{r}$. Bydgoszcz była pod zaborem pruskim, a po 1920 r. wróciła w granice państwa polskiego). Działalność zakładów w analizowanym okresie była ważnym elementem gospodarki miejscowej i państwowej.

Abstract: The aim of this article is to trace the history of the tobacco industry in Bydgoszcz from the mid-19th century until the establishment of the Polish Tobacco Monopoly in 1922. The research was conducted using the records of Commercial Register Records (Akta Rejestru Handlowego), the City of Bydgoszcz Records (Akta miasta Bydgoszczy), and the Construction Records of the City of Bydgoszcz (Akta budowlane miasta Bydgoszczy) from the years 1850-1925. Archival information was supplemented with data from the daily press from the years 1908-1924. The research topic was presented against the background of the political and economic situation of the city (until 1920 Bydgoszcz was under Prussian rule, and after 1920 returned to the territory of the Polish state). The activity of tobacco factories in the analysed period was an important element of both the local and state economy.
\end{abstract}

Słowa kluczowe: Bydgoszcz, przemysł tytoniowy, historia, XIX/XX wiek, topografia

Key words: Bydgoszcz, tabacco industry, history, 19th/20th century, tophography

Historia bydgoskiego przemysłu jest coraz częściej badana i analizowana. Dzięki przywracaniu pamięci o dziedzictwie industrialnym w 2012 r. powstał w mieście szlak tematyczny $\mathrm{TeH}_{2} \mathrm{O}^{1}$ łączący miejsca, w których w XIX i XX w. rozwijał się miejscowy przemysł i rzemiosło. Jak ważne jest lokalne dziedzictwo przemysłowe i poprzemysłowe potwierdziło ogłoszenie przez Radę Miasta Bydgoszczy roku 2018 Rokiem Bydgoskiego Dziedzictwa Przemysłowego. Nie znaczy to, że powiedziano i napisano już wszystko. Warto poszerzać wiedzę ten temat, przypominając $\mathrm{np}$. tradycje związane $\mathrm{z}$ istniejącym tu przemysłem tytoniowym. Niniejszy artykuł koncentruje się na przedstawieniu historii fabryk wyrobów tytoniowych działających w Bydgoszczy, z uwzględnieniem ich działalności, profilu produkcji, zmian właścicieli. Niemniej ważne jest określenie ich usytuowania we współczesnym układzie urbanistycznym, bowiem ich funkcjonowanie zakończyło się przed zmianą numeracji i częściową zmianą nazw ulic, co w Bydgoszczy nastąpiło na początku lat trzydziestych XX w. Z tego powodu odtworzenie obecnie ich pierwotnej lokalizacji jest utrudnione.

1 „Szlak Wody, Przemysłu i Rzemiosła $\mathrm{Te}_{2} \mathrm{O}$ w Bydgoszczy (przemysłowy szlak tematyczny)”; rozwinięcie skrótu: $\mathrm{Te}$ - technika, $\mathrm{H}$ - historia, ${ }_{2} \mathrm{O}$ - dwa razy opowieść. 
W czasach, gdy Bydgoszcz znalazła się pod zaborem pruskim i w pierwszych latach po odzyskaniu przez Polskę niepodległości, bydgoski przemysł tytoniowy nadal był w mieście obecny. Historia prywatnych zakładów tytoniowych skończyła się w roku 1922, w momencie ustanowienia Polskiego Monopolu Tytoniowego (dalej cyt.: PMT). W 1939 r. funkcjonował już tylko jeden zakład, kontrolowany przez PMT, powstały na bazie Fabryki Cygar braci Adam, o dziewiętnastowiecznej genezie.

W podzielonej między zaborców Polsce moc miały regulacje prawne tych państw. W zaborze pruskim nie obowiązywał monopol tytoniowy, w przeciwieństwie do pozostałych dwóch — austriackiego i rosyjskiego, gdzie przemysł tytoniowy był w pełni kontrolowany. Mimo że w Niemczech był on wysoko opodatkowany, to i tak przynosił inwestorom duże dochody ${ }^{2}$.

Na terenie Wielkopolski tytoń uprawiano od końca XVIII w., a tradycję tę zapoczątkowali w okolicach Rogoźna i Mieściska osadnicy z południowych i zachodnich Niemiec, sprowadzeni na te tereny za czasów panowania Fryderyka Wielkiego ${ }^{3}$. W 1879 r. wprowadzono podatek, którego wysokość zależała od wagi zebranych liści, zaś w 1893 r. przygotowywano przepisy umożliwiające nałożenie przez rząd Rzeszy Niemieckiej podatku fabrycznego od tytoniu ${ }^{4}$. W pierwszej połowie XIX w. na terenie ziem polskich pod zaborem pruskim działały fabryki tytoniu w Bojanowie, Bydgoszczy, Dolsku, Gostyniu, Koronowie, Kcyni, Mosinie, Obornikach, Rawiczu, Wschowie i Zaniemyślu. W 1910 r. produkcja tytoniu na obszarze Prus Wschodnich, Prus Zachodnich, Pomorza, Poznańskiego i Śląska przerosła wskaźniki galicyjskie $^{5}$. Tereny te były najdalej wysuniętymi na północ Europy, na których uprawiano tytoń. Niskie temperatury, wilgotność i niedostateczne nasłonecznienie miały jednak negatywny wpływ na jakość surowca ${ }^{6}$.

Produkcję uzupełniano importując liście tytoniu. W latach 1880-1885 to 60\% surowca pochodziło w Cesarstwie Niemieckim z krajowych plantacji, 40\% sprowadzono z Kuby, Meksyku, Brazylii, Jawy, Sumatry i Borneo ${ }^{7}$. Miejsca pochodzenia tytoniu zastąpiły w praktyce nazwy botaniczne, stąd pojawiające się w literaturze przedmiotu nazwy takie jak tytoń „Sumatra”, „Jawa”, „Brasil”, „Kuba”, „Havana”, tytonie „tureckie”, „kaukaskie”, „galicyjskie”.

$\mathrm{Na}$ dynamiczny rozwój niemieckiego przemysłu tytoniowego na początku XX w. wpływ miały zamówienia rządowe dla wojska. Wyroby, przede wszystkim papierosy - w tym te z bydgoskich fabryk — wysyłano do koszar i do okopów podczas pierwszej wojny światowej ${ }^{9}$. Po 1920 r., w byłej dzielnicy pruskiej, w przemyśle tytoniowym produkującym cygara, papierosy i tabakę do zażywania i palenia, zatrudnionych było od 8 do 10 tysięcy osób, nie licząc zależnych od niego tzw. przemysłów pomocniczych, czyli zajmujących się wyrobem bibułek, kartonów, pudełek, etykiet i plakatów reklamowych ${ }^{10}$. Po zakończeniu Wielkiej Wojny i odzy-

2 AP Bydgoszcz, AbmB, sygn. 69. Właściciela składu tytoniu Reiholda Napiewockiego stać było w $1901 \mathrm{r}$. na postawienie okazałej, czterokondygnacyjnej kamienicy przy reprezentacyjnej ulicy w Bydgoszczy Wilhelmstrasse 17 (obecnie ul. Marszałka Focha 4, projekt Carl Bergner).

${ }^{3}$ Fiedler L.K. 1923, s. 67.

${ }^{4}$ Marcinek R. 2012, s. 245. W zaborze rosyjskim dozwolona była uprawa tytoniu, opodatkowano przemysł i handel (wprowadzono banderole na wszystkie wyroby), zaś w zaborze austriackim monopolem objęta była uprawa, przemysł $\mathrm{i}$ handel.

${ }_{5}^{5}$ Marcinek R. 2012, s. 319.

${ }^{6}$ Głowacka I. 2020, s. 26.

${ }^{7}$ Uprawa. 1926, s. 5; Tabakindustrie. 1907, s. 246.

${ }^{8}$ Skulski J. 1920, s. 8-9. Tytoń to roślina zielona z rodziny psiankowatych, obejmuje ok. 70 gatunków. Do wyrobu tytoniu używa się przede wszystkim tytoń szlachetny (Nicotana tabacum) i tytoń bakun (Nicotana rustica).

${ }^{9}$ Anons. 1916, s. 4.

${ }^{10}$ Fiedler L.K. 1923, s. 49. 
skaniu przez Polskę niepodległości fabryki wyrobów tytoniowych nadal prowadzili przedwojenni właściciele lub zakłady odkupywali od Niemców polscy przedsiębiorcy.

Po 1922 r. sytuacja radykalnie się zmieniła. 1 czerwca tego roku wprowadzono ustawę o Polskim Monopolu Tytoniowym. Dawała ona skarbowi państwa wyłączne prawo produkcji, importu i sprzedaży surowca tytoniowego i wyrobów tytoniowych ${ }^{11}$. W 1924 r. prywatny przemysł tytoniowy przestał w Polsce oficjalnie istniećl2 ${ }^{12}$ Skończyła się też historia bydgoskich prywatnych przedsiębiorstw produkujących tytoń, cygara i papierosy. Nie znaczy to jednak, że w układzie urbanistycznym Bydgoszczy nie pozostały ślady tej gałęzi przemysłu.

Artykuł ma na celu wskazanie takich miejsc w topografii miasta i odtworzenie ich historii. Na potrzeby tego opracowania przeanalizowano „Akta budowlane miasta Bydgoszczy”, „Akta miasta Bydgoszczy” oraz „Akta Rejestru Handlowego”. Dla ustalenia miejsc i przybliżonego czasu funkcjonowania fabryk cenne okazały się informacje zawarte w księgach adresowych miasta Bydgoszczy z lat 1850-1925. Uzupełnienie stanowią anonse z lokalnej prasy; przede wszystkim prześledzono reklamy i ogłoszenia ukazujące się w „Dzienniku Bydgoskim” od 1908 do 1924 r. Na początku lat dwudziestych XX w. „Tygodnik Ilustrowany” zamieścił cykl tekstów poświęconych przemysłowi i rzemiosłu bydgoskiemu, w tym fabrykom tytoniu, papierosów i cygar. Zawarte w nich wiadomości wzbogaciły zasób danych, zwłaszcza na temat produkowanego asortymentu. Przeprowadzone badania terenowe pozwoliły natomiast opisać współczesny stan zachowania dawnych kompleksów fabrycznych.

O bydgoskim przemyśle tytoniowym do tej pory ukazał się tekst w Industrie und Gewerbe in Bromberg w 1907 r., w którym wymieniono wiodące, miejscowe firmy produkujące tytoń, cygara i papierosy, działające na początku XX w. ${ }^{13}$, następnie artykuły opublikowane w ostatnich kilkunastu latach — Marka K. Jeleniewskiego ${ }^{14}$ i Agnieszki Wysockiej ${ }^{15}$. Omówienie wybranych zakładów tytoniowych znalazło się w opracowaniu Bogny Derkowskiej-Kostkowskiej dotyczącym bydgoskich warsztatów i fabryk ${ }^{16}$.

W 1772 r. na mocy traktatów rozbiorowych Bydgoszcz stała się częścią państwa pruskiego. Zniszczone wojnami, upadłe gospodarczo miasto zamieszkiwało ok. 1000 osób. Atutem dostrzeżonym przez zaborcę było jego położenie geograficzne. Władze pruskie uczyniły z Bydgoszczy ośrodek administracyjny i ulokowały tutaj garnizon wojskowy. Impulsem dla rozwoju gospodarczego była decyzja o budowie drogi wodnej, czyli Kanału Bydgoskiego łączącego Brdę z Notecią, a przez dopływy — dolną Wisłę z Wartą i Odrą ${ }^{17}$.

Okres kolejnego przyspieszenia przypadł na lata trzydzieste i czterdzieste XIX w., co związane było z początkiem industrializacji na terenie Prus. Wzrost zapotrzebowania na maszyny rolnicze i urządzenia dla przetwórstwa rolnego skutkował powstawaniem takich zakładów także w Bydgoszczy. Po nich przyszedł czas na rozwój przemysłu drzewnego i meblowego. Najważniejszym momentem dla miejscowej gospodarki było włączenie miasta w sieć Kolei Wschodniej, budowanej w latach 1848-1851. Do Bydgoszczy, w której mieszkało w tym czasie ok. 22 tysięcy mieszkańców ${ }^{18}$, docierały ,żelaznymi drogami” surowce potrzebne do produkcji, a także wyjeżdżały towary do coraz odleglejszych rynków zbytu ${ }^{19}$.

11 Kaliszczuk M. 1981, s. 108-109.

12 Katalog wystawy. 1929, s. 5-6.

13 Tabakindustrie. 1907, s. 245-247.

14 Jeleniewski M.K. 2009, s. 111-122.

15 Wysocka A. 2016, s. 47-56.

16 Derkowska-Kostkowska B. 2018.

17 Mincer F. 1991, s. 379-380.

18 Jastrzębska-Puzowska I. 2005, s. 12; w 1900 r. liczba mieszkańców Bydgoszczy wzrosła do 79 tysięcy.

19 Wajda K. 1991, s. 530. 
Transport kolejowy zapewniał również przemysłowi tytoniowemu dostęp do surowców. Liczyła się szybkość i warunki, w jakich tytoń docierał do fabryk. Wysuszone liście tytoniu nie są bowiem odporne na wilgoć, szybko pleśnieją, ulegają zanieczyszczeniu. Zakłady zajmujące się jego obróbką musiały być wyposażone w suche i zacienione magazyny z dobrą wentylacją, w sortownie (do których liście trafiały dwukrotnie — przed i po procesie fermentacji), także w pomieszczenia do poddawania liści procesowi fermentacji oraz w ręczne lub maszynowe krajalnie. W zależności od rodzaju wyrobów następowała fabrykacja tytoniu, papierosów lub cygar. Przygotowanie tych ostatnich było najbardziej skomplikowane i czasochłonne. Ostatnie etapy prac odbywały się w sortowni i w pakowalni (paczkowalni). Gotowe wyroby czekały zaś na odbiorców w magazynach. Pojawienie się w Bydgoszczy przemysłu tytoniowego zbiegło się w czasie z małą ,rewolucją” w produkcji papierosów. Ręczną pracę częściowo zastąpiła maszynowa dzięki wynalazkowi „maszyny do zwijania papierosów”20.

Adresy pierwszych warsztatów i fabryczek produkujących tytoń, cygara i papierosy są trudne do ustalenia. W pojawiających się w miejscowej prasie ogłoszeniach i reklamach tych firm zazwyczaj podawano tylko nazwy ulicy lub nazwiska właścicieli. W połowie XIX w. w Bydgoszczy działało ośmiu wytwórców i handlarzy papierosów oraz tabaki. Byli wśród nich: Joseph von Janowski, który przy ul. Długiej 31 (Friedrichstrasse 53) w 1850 r. założył firmę „J. Janowski” łączącą sprzedaż i produkcję (ryc. 1).

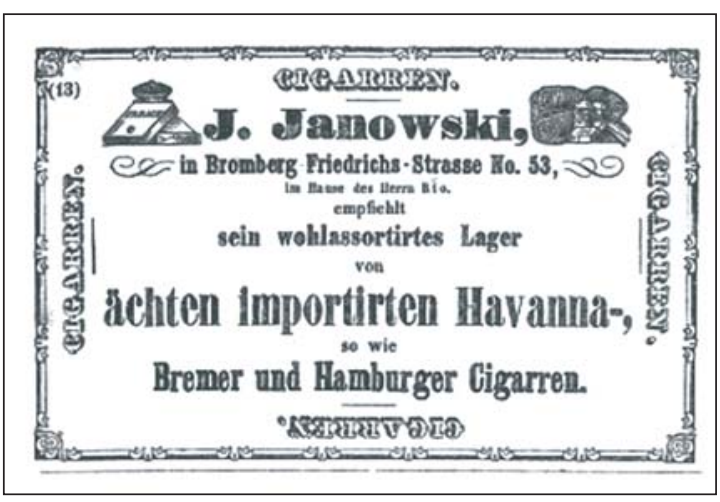

Ryc. 1. Reklama fabryki i hurtowni wyrobów tytoniowych J. Janowskiego z $1855 \mathrm{r}$. (źródło: Księga adresowa. 1855, s. 184)

Fig. 1. Advertisement of the tobacco factory and wholesaler J. Janowski from 1855 (source: Address book. 1855, p. 184)

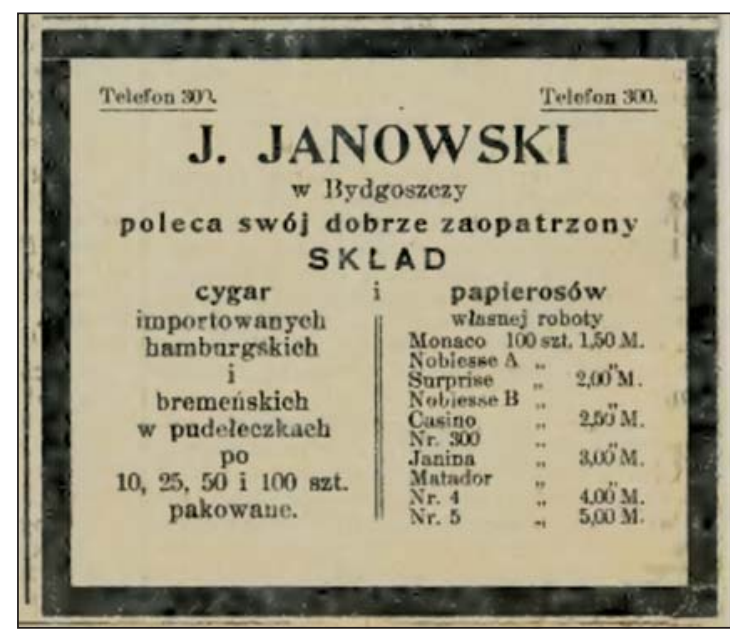

Ryc. 2. Reklama fabryki i hurtowni wyrobów tytoniowych J. Janowskiego z $1908 \mathrm{r}$. (źródło: Anons. 1908b, s. 4)

Fig. 2. Advertisement of the tobacco factory and wholesaler J. Janowski from 1908 (source: Anons. 1908b, p. 4)

${ }^{20}$ Ferland C. 2007, s. 37. Pierwsza maszyna do zwijania papierosów (le cigarettotype) skonstruowana przez Françoisa Le Maire w latach 1843-1844 produkowała 3600 papierosów na godzinę. W 1881 r. James Bonsack, amerykański wynalazca, opatentował przemysłową maszynę do zwijania papierosów. Jej wydajność to 15000 papierosów na godzinę. 
Fabrykę i hurtownię w 1898 r. przejął Marian von Janowski (brat?) i kierował nią do 1917 r. przy ul. Długiej 33 (Friedrichstrasse 54). Oferowała ona, wciąż pod marką „J. Janowski”, wyroby importowane, takie jak cygara z Hamburga i Bremy oraz ręcznie robione na miejscu papierosy $^{21}$ (ryc. 2). O kolejnych firmach wiadomo nieco więcej.

Poniżej zamieszczam wykaz zidentyfikowanych firm oraz ich opis zawierający podstawowe, możliwe do ustalenia dane: nazwę, właściciela, okres funkcjonowania, marki produktów, umiejscowienie fabryki.

Fabryka Tabaki Dawida Woythalera (Woythaler Schnupftabak-Fabrik);

adres obecny: ul. Marszałka Focha 18 (dawne adresy: Wilhelmstrasse 10; ul. Jagiellońska 10); właściciel: David (Dawid) Woythaler; czas funkcjonowania: 1871-1922; marka wiodąca: „Kownoer” — tabaka kowieńska (dane z 1907 r.); teren fabryki obecnie: zachowana zabudowa pofabryczna (funkcja mieszkalno-usługowo-biurowa) (ryc. 3).

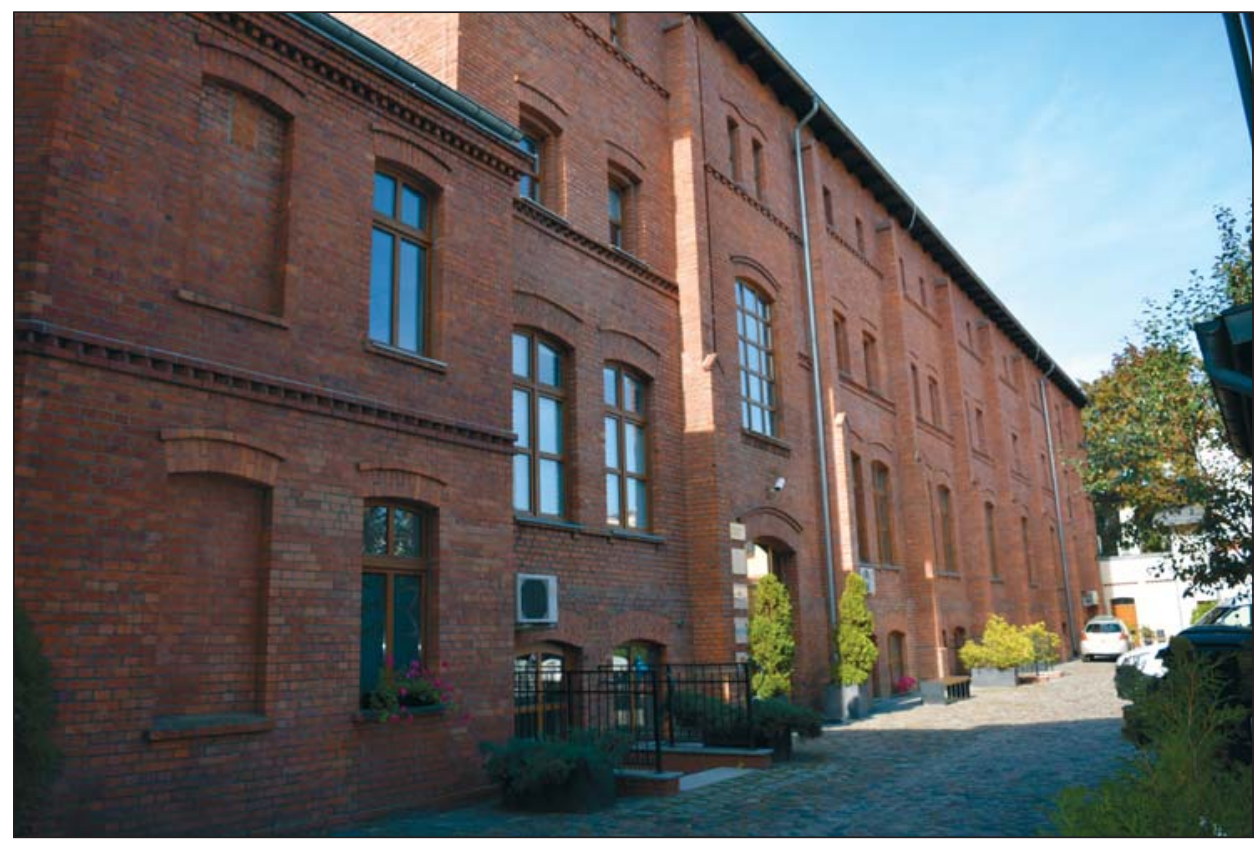

Ryc. 3. Zabudowa pofabryczna dawnej Fabryki Tabaki Davida Woythalera na parceli przy obecnej ul. Focha 18 (fot. A. Wysocka, 2021 r.)

Fig. 3. Former factory buildings of David Woythaler's Snuff Factory (Fabryka Tabaki Davida Woythalera) on a plot of land located at the present-day 18 Focha St. (photo by A. Wysocka, 2021)

Firma działała od 1 października 1871 r. i rozwijała się na tyle dobrze, że w 1893 r. D. Woythaler rozbudował fabrykę i zainstalował jako pierwszy w Bydgoszczy maszyny parowe do rozdrabniania wysuszonych liści tytoniu. Rocznie produkowano 330000 kilogramów tabaki. W 1907 r. należała do największych fabryk tabaki w Cesarstwie Niemieckim. W 1921 r. po-

${ }^{21}$ Tabakindustrie. 1907, s. 246-247. Budynki frontowe przy ul. Długiej 31 i 33 nadal istnieją. Pełnią funkcję mieszkalno-handlowo-usługową. 
wstała filia fabryki w Berlinie-Lankwitz. Koniec historii zakładu to rok 1922. Na terenie nieruchomości nowy właściciel — Edward Józef Pawłowski uruchomił Drukarnię Narodową Towarzystwo Akcyjne ${ }^{22}$.

Fabryka Cygar Adama (Adam's Zigarrenfabrik); adres obecny: ul. Dworcowa 110 (dawne adresy: Banhofstrasse 44; ul. Dworcowa 44); właściciele: Julius Adam, Isbert Adam; czas funkcjonowania: 1878-1924 (1878-ok. 1905 przy obecnej ul. Gdańskiej 54; ok. 1905-1924 przy ul. Dworcowej 110);

marki wiodące: „Adams” (dane z 1923 r.);

teren fabryki obecnie: budynek Polskiego Monopolu Tytoniowego z 1927 r. (funkcja biurowo-usługowa).

Wytwórnia powstała w 1878 r. przy ul. Gdańskiej 54 i zatrudniała ok. 20 pracowników. Jej pierwszym właścicielem był Julius Adam (1859-1919). Roczna produkcja wynosiła 1 milion cygar. Mimo dużego popytu właściciel nie mógł zwiększyć produkcji z powodu braku wykwalifikowanych robotników. W 1901 r., m.in. dzięki organizowanym w fabryce szkoleniom dla robotnic, liczba pracowników wzrosła do 50 osób. Dwa lata później współwłaścicielem fabryki został brat Juliusa - Isbert. Dobrze rozwijające się przedsiębiorstwo na początku XX w. dokonało zakupu parceli niedaleko dworca kolejowego (kwartał zabudowy przy obecnych ulicach Dworcowej/Unii Lubelskiej/Warszawskiej) pod nowe zabudowania fabryczne. W nowo wybudowanym kompleksie pracowało 130 osób. W 1906 r. Adam’s Zigarrenfabrik uruchomił także filię w Elblągu z 60 pracownikami. W obu fabrykach w 1907 r. wyprodukowano 10 milionów cygar średniej i wysokiej jakości. Surowiec do produkcji sprowadzano z Ameryki Północnej i Południowej oraz z Indii Zachodnich. Używano tytoni: „Sumatra”, „Java”, „Brasilia”, „Havana”. Nazwy wytwarzanych cygar to: „Patentes”, „Princesas”, „Exuisitos”, „Piccolo”, „Piccolo Extra”, „Havanillos”, „Poniatowski”, „Regalia” i „Gaudeamus”23.

Po śmierci brata i krótkim epizodzie współprowadzenia fabryki z wdową i synem po Juliusie (Martą i Zygfrydem Adam), Isbert Adam od 1922 r. zarządzał firmą samodzielnie. Otworzył filie w Grudziądzu (zatrudniającą 165 pracowników) i w Inowrocławiu (155 pracowników) ${ }^{24}$ oraz w Gdańsku ${ }^{25}$. Bydgoski zakład i jego ekspozytury produkowały rocznie 25 milionów cygar (dane z 1923 r.) $)^{26}$. 1 sierpnia 1924 r. firmę odsprzedano Skarbowi Państwa i przeszła ona pod zarząd Polskiego Monopolu Tytoniowego. Po gruntownej rozbudowie w drugiej połowie lat dwudziestych XX w. funkcjonowała do 1939 r. jako Państwowa Fabryka Wyrobów Tytoniowych w Bydgoszczy ${ }^{27}$.

Fabryka Cygar i Tabaki Eduarda Löwenthala (Löwenthal Zigarren \& Tabak Fabrik/ Löwenthal's Sohne Zigarren \& Tabak Fabrik); Fabryka Cygar Norberta Beume; Fabryka Cygar Wiktora Konkolewskiego; adres obecny: ul. Gdańska 80/80a (dawne adresy: Danzingerstrasse 129; ul. Gdańska 129); właściciele: Eduard Löwenthal (do 1903 r.), Norbert Beume (do 1922 r.), Wiktor Konkolewski (do 1924 r.); czas funkcjonowania: 1898-1924;

${ }^{22}$ AP Bydgoszcz, AmB, sygn. 47 i AbmB, sygn. 54; Tabakindustrie. 1907, s. 247-248.

${ }^{23}$ Adama Cygara. 1923, s. 474.

${ }^{24}$ Derkowska-Kostkowska B. 2018, s. 36-37.

${ }^{25}$ Fabryka. 1920, s. 2. W artykule tym wymieniono filię w Berlinie, ale nie udało się potwierdzić tej informacji.

${ }^{26}$ Adama Cygara. 1923, s. 474.

27 Wysocka A. 2016, s. 47-56. 
marka wiodąca: „La Paz” (dane z 1923 r.);

teren fabryki obecnie: zabudowa nieistniejąca.

Powstanie firmy datowane jest na rok 1848, niestety nie udało się ustalić jej pierwszego właściciela oraz wcześniejszej lokalizacji ${ }^{28}$. Na parceli przy ul. Gdańskiej 80/80a zakład notowany jest we wrześniu 1898 r., gdy kupiec Eduard Löwenthal wnioskował do Wydziału Budowlanego o budowę jednopiętrowej fabryki przylegającej do frontowej kamienicy. Pracę wykonano według projektu miejscowego mistrza murarskiego Georga Weissa w tym samym roku. Pod jego nadzorem przebudowano również na magazyn tytoniu dawną stajnię oraz postawiono otwartą szopę (przypuszczalnie przeznaczoną do składowania surowca). W $1903 \mathrm{r}$. nowym właścicielem fabryki został Norbert Beume. Przeniósł on do Bydgoszczy fabrykę cygar, którą założył w Jastrowie. Ok. 1907 r. N. Beume zatrudniał 80 pracowników ${ }^{29}$. W latach 1910-1913 przeprowadził kolejne zmiany w kompleksie fabrycznym według projektów Waltera Zagermanna i E. Kelma. Nadbudowano wówczas szopę, dobudowano jadalnię i szatnię dla pracowników ${ }^{30}$. Fabryka należała do N. Beume do roku 1922, gdy odkupił ją Wiktor Konkolewski, zatrudniając 125 pracowników. Sprowadzany z zagranicy surowiec to tytoń „Brazylia”, „Sumatra”, „Java”, „Hawana”. Cygara produkowano tam pod markami „Adona”, „Aromatica”, „Calidad”, „Polska krew”, a najbardziej luksusową był „Magnat”. Dzienna produkcja cygar wynosiła 30000 sztuk. Fabryka wytwarzała także cygaretki ${ }^{31}$, które sprzedawano pod nazwami „Angelico” i „Rita”32. W zabudowaniach dawnej fabryki cygar w 1936 r. uruchomiono wytwórnię obuwia „Helios" ${ }^{33}$.

Fabryka Cygar Leopolda Landsbergera (Landsberg Zigarrenfabrik); Fabryka Cygar Juliusa Garstena (Garsten Zigarrenfabrik); Bydgoska Fabryka Cygar. Towarzystwo Akcyjne w Bydgoszczy; adres obecny: ul. Łokietka 36 (dawny adres: Prinzenstrasse 19; ul. Łokietka 19) (ryc. 4);

właściciele: Leopold Landsberger (18991909), Julius Garsten (1909-1920), spółka kupców bydgoskich branży tytoniowej (1920-1924);

czas funkcjonowania: 1899-1923/1924; marki wiodące: „Perła Bydgoszczy”, „Helios” (dane z 1923 r.);

teren fabryki obecnie: zabudowa nieistniejąca.

Czterej bydgoscy kupcy branży tytoniowej (właściciele hurtowni i sklepów z wyrobami tytoniowymi i z alkoholem) Franciszek Ormanowski, Władysław Turowski, Stanisław Nagel i Jan Woyke zawiązali w 1920 r. spółkę, która wykupiła

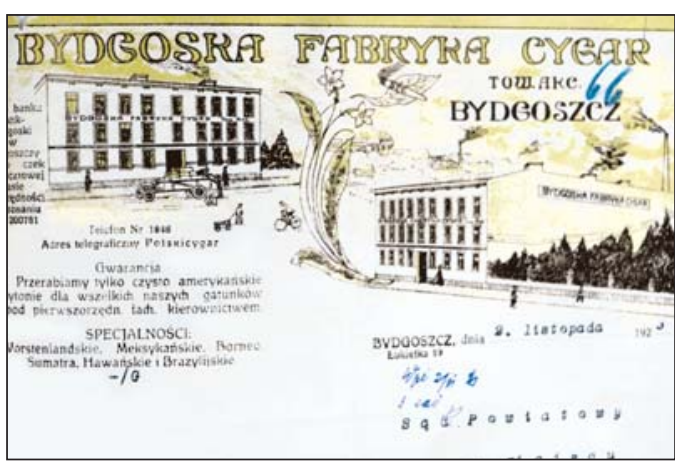

Ryc. 4. Winieta papieru firmowego Bydgoskiej Fabryki Cygar (źródło: AP Bydgoszcz, ARH, sygn. 807)

Fig. 4. Vignette of the letterhead of Bydgoszcz Cigar Factory (Bydgoska Fabryka Cygar) (source: AP Bydgoszcz, ARH, inventory No. 807)

28 75-lecie. 1923, s. 176.

29 Tabakindustrie. 1907, s. 246-247.

30 AP Bydgoszcz, AbmB, sygn. 3959-3960.

${ }^{31}$ Cygaretka - małe cygaro z warstwą zewnętrzną wykonaną z liścia tytoniu, o długości 7-10 cm, o zawartości ok. $3 \mathrm{~g}$ tytoniu, wyposażone w ustnik.

32 75-lecie. 1923, s. 178.

33 AP Bydgoszcz, AbmB, sygn. 3960. 
Fabrykę Cygar Garstena ${ }^{34}$ i powołała Bydgoską Fabrykę Cygar ${ }^{35}$. Jej kierownictwo powierzyli Fryderykowi Rosianowi, długoletniemu pracownikowi Fabryki Loesser \& Wolff w Elblągu. Na potrzeby nowego przedsiębiorstwa spółka kupiła nieruchomość przy ul. Łokietka 36 (kamienica frontowa z 1885 r. wraz z zabudową gospodarczą na parceli). W 1920 r. zatrudniano tu pięciu pracowników, zaś rok później już 125 osób, trzech dyrektorów — Fryderyka Rosiana, Franciszka Gońskiego i Czesława Biernackiego oraz trzech kierowników produkcji. W skład rady nadzorczej wchodził M. Sentkowski jako prezes oraz Stanisław Nagel i Henryk Kaszubowski. W 1922 r., w pierwszym roku pełnej produkcji, fabryka wyrabiała 75 000-100 000 cygar tygodniowo, a jej bilans zamknięto zyskiem 6 milionów marek polskich. Do 1923 r. kapitał zakładowy zwiększył się z 8 do $100 \mathrm{mln}$ marek polskich. Poza wiodącymi markami zwijano cygara gatunku średniego („Salonowe”, „Talento”, „Wandzia”), przedniego („Kościuszko”, „Smakosz”, „Industria”, „Światowe”, „Mój gatunek”), najprzedniejszego („Senior”, „Sportowe”, „Par Force”, „La Defenza”) oraz luksusowe („Bydgoska Industria”, „Beata”, „Nasza Chluba”, „Filipianas”, „Bydgoska Industria Wielka”) ${ }^{36}$.

Fabryka Papierosów i Tabaki „Bessarabia” (Zigaretten \& Tabak Fabrik „Bessarabia”); Fabryka Rosyjskich Papierosów „Bessarabia” (Russiche Zigaretten Fabrik „Bessarabia”); Fabryka Papierosów i Tabaki do zażywania „Bessarabia” (Zigaretten \& Schnupftabak Fabrik „Bessarabia");

adres obecny: ul. Gdańska 109 (dawne adresy: Danzingerstrasse 61; ul. Gdańska 61) (ryc. 5);

właściciel: Józef Pawłowski; czas funkcjonowania: 1900-1914; marka wiodąca: papierosy „,Delikat Bessarabia Spezial" (dane z 1910 r.) (ryc. 6);

teren fabryki obecnie: na parceli zachowany jeden $\mathrm{z}$ dawnych budynków pofabrycznych (znajduje się tam restauracja).

Działalność firmy przypada na pierwsze lata XX w. ${ }^{37}$, a wyróżniało ją to, że właściciel był Polakiem, co w silnie zgermanizowanej Bydgoszczy stanowiło wyjątek. W skład rady nadzorczej wchodzili miejscowi polscy kupcy i przedsiębiorcy:

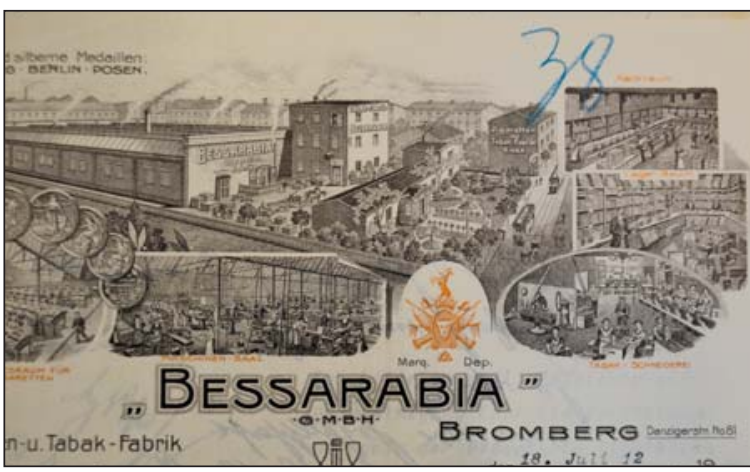

Ryc. 5. Winieta papieru firmowego Fabryki Papierosów i Tabaki „Bessarabia”

(źródło: AP Bydgoszcz, ARH, sygn. M 31)

Fig. 5. Vignette of the letterhead of the "Bessarabia" Cigarette and Snuff Factory (Fabryka Papierosów i Tabaki "Bessarabia")

(source: AP Bydgoszcz, ARH, inventory No. M 31)

M. Sentkowski, Złotowski, Kiełczyński, L. Krzywiński. Od 1909 r. zakład produkował tylko papierosy, zarzucając produkcję tytoniu i zmieniając pierwotną nazwę na „Fabryka Rosyjskich Papierosów "Bessarabia»"38. Do ich wyrobu sprowadzano tytoń z Turcji i Rosji, z którego wytwarzano papierosy „Mon Plaisir”, „Goldelschen”, „Aplex”, „Noblesse” i „Alupka”39. Wła-

34 AP Bydgoszcz, ARH, sygn. 3730.

35 AP Bydgoszcz, ARH, sygn. 807, zachowane „Sprawozdania Bydgoskiej Fabryki Cygar. Towarzystwa Akcyjnego" z lat 1921, 1922 i 1923.

36 Cajus. 1923b, s. 192.

37 AP Bydgoszcz, ARH, sygn. M 31.

38 AP Bydgoszcz, ARH, sygn. M 31.

39 Anons. 1909, s. 4. „Tabakę Kowieńską wytwarzano w dwóch odmianach — „zielonej” i „żółtej”, „Wiatrówka" miała smak miętowy. 
ściciel firmy J. Pawłowski był zarazem autorem artykułów o hodowli tytoniu, co sugeruje, że przebywał na terenach, skąd pochodził tytoń sprowadzany do jego bydgoskiej fabryki, czyli w Turcji i w Rosji ${ }^{40}$. W 1910 r. w nowopowstałym budynku na terenie fabryki otwarto linię produkcyjną tabaki. Proponowano „Tabakę Kowieńską” i „Wiatrówkę"41. W tym samym roku „Bessarabia” zaprezentowała swoje wyroby na Wystawie Przemysłowej w Bydgoszczy, na której za tabakę otrzymała złoty medal ${ }^{42}$. Firma posiadała składy hurtowe w Berlinie (na Środkowe Niemcy), w Bochum (na Westfalię i Nadrenię) oraz w Liège (na Belgię i Holandię) ${ }^{43}$. Praca $w$ fabryce była częściowo zmechanizowana. Zakład dzielił się na następujące działy: krajalnia tytoniu, wyrób papierosów ręczny i maszynowy, wyrób kartonów i opakowań z tłocznią ,która złoty druk na opakowaniach wykonuje"44. Kłopoty finansowe firmy wynikały z niewielkiego kapitału zakładowego, co przy dużej konkurencji na rynku doprowadziło do poważnego kryzysu na przełomie 1913 i 1914 r. Wówczas J. Pawłowski ogłosił jej upadłośćc ${ }^{45}$.

Fabryka Tabaki Franza Lehmanna (Franz Lehmann. Tabakfabrik); Fabryka Papierosów, Tytoni i Gilz „Druh” (ryc. 7);

adres obecny: ul. Poznańska 16 (dawne adresy: Posenerstrasse 28; ul. Poznańska 28); właściciel: Franciszek (Franz) Lehmann; czas funkcjonowania: 1909-1923/1924; marka wiodąca: tytoń „Machorka” (dane z 1923 r.); teren fabryki obecnie: zabudowa nieistniejąca.

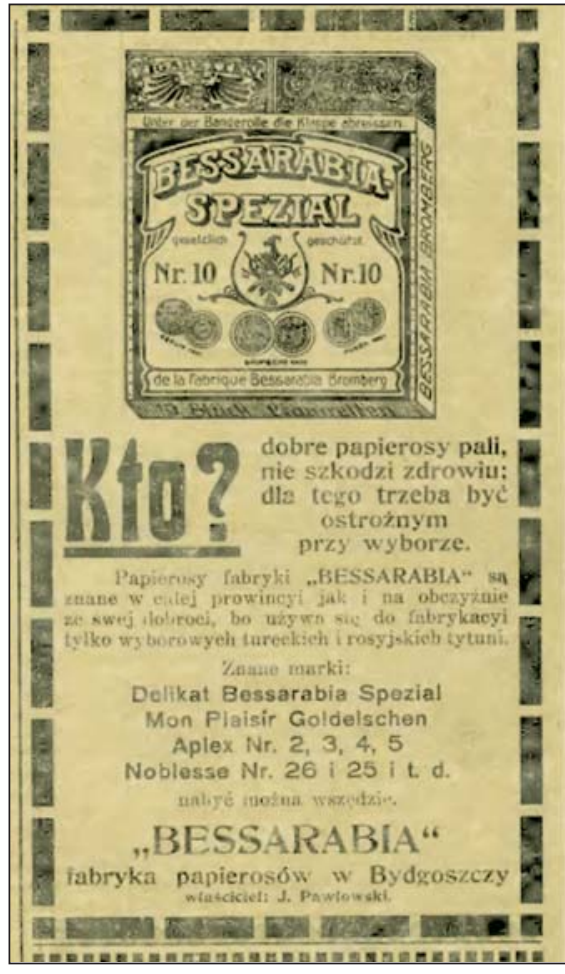

Ryc. 6. Reklama Fabryki Papierosów i Tabaki „Bessarabia”

(źródło: Anons. 1908a, s. 4)

Fig. 6. Advertisement of the "Bessarabia" Cigarette and Snuff Factory (Fabryka Papierosów i Tabaki "Bessarabia") (source: Anons. 1908a, p. 4)

W 1909 r. powstała Fabryka Tabaki pod nazwą Franz Lehmann. Tabakfabrik. Właściciel firmy został powołany w $1918 \mathrm{r}$. do armii niemieckiej i wysłany na front wschodni, gdzie ,przeszedł całą Ukrainę i Macedonię, zwiedził Odessę, Chersoń, Mikołajów, oglądał po drodze słynne plantacje rosyjskiego i macedońskiego tytuniu" ${ }^{46}$. Po powrocie do Bydgoszczy w 1920 r. F. Lehmann przekształcił swój zakład w Fabrykę Papierosów, Tytoniu i Gilz „,Druh”. Rozbudował go w 1921 r. i tym samym jego firma zajmowała na parceli siedem budynków i szopę, gdzie składowano tytoń ${ }^{47}$.

40 Pawłowski J. 1908a, s. 2; Pawłowski J. 1908b, s. 2, autor pisze m.in., że: „Ilość wyrabianych obecnie w Niemczech papierosów wynosi około 6 miliardów sztuk rocznie", Pawłowski J. 1908c, s. 2; Pawłowski J. 1908d, s. 2.

41 Anons. 1910, s. 4.

42 Spis nagród. 1910, s. 2.

43 Ogłoszenie. 1909, s. 4.

${ }^{44}$ Zwiedzanie. 1913, s. 2.

45 Smutna wiadomość. 1914, s. 3.

46 Quis. 1923b, s. 94-95.

${ }^{47}$ AP Bydgoszcz, AbmB, sygn. 5646-5647. 


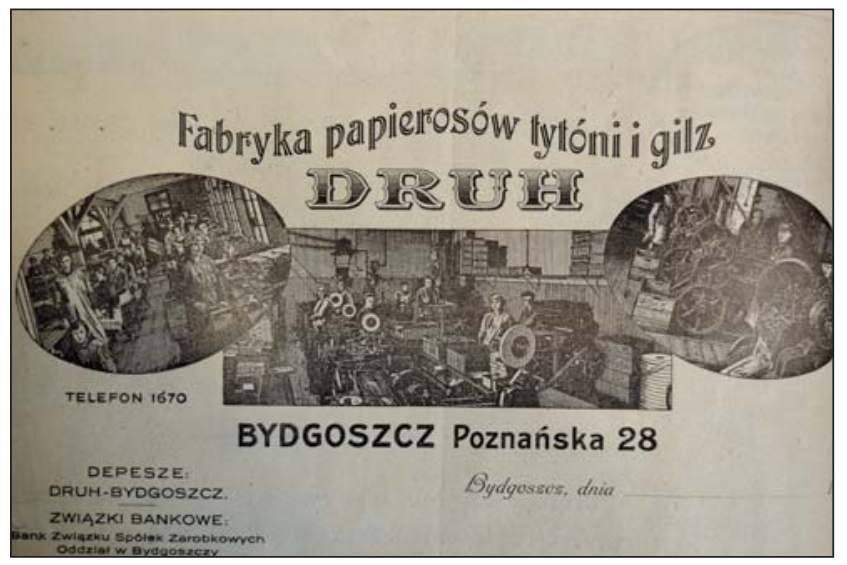

Ryc. 7. Winieta papieru firmowego Fabryki Papierosów, Tytoni i Gilz „Druh” (źródło: AP Bydgoszcz, ABmB, sygn. 5645)

Fig. 7. Vignette of the letterhead of the "Druh" Factory of Cigarettes, Tobacco, and Rolling paper (Fabryka Papierosów, Tytoni i Gilz "Druh") (source: AP Bydgoszcz, $\mathrm{ABmB}$, inventory No. 5645)

W kompleksie znajdowały się trzy krajalnie tytoniu, dział fabrykacji papierosów i gilz ${ }^{48}$, oddział pakowania tytoniu, drukarnia i introligatornia. Towar rozwożono własnym samochodem. W $1921 \mathrm{r}$. zatrudnionych było 120 robotników nadzorowanych przez dwóch majstrów oraz pięciu pracowników biurowych (kantorzystów). Dziennie przerabiano 2000 kilogramów tytoniu i wyrabiano 100000 sztuk papierosów, składano 300000 sztuk gilz. Tytoń sprowadzano z zagranicy. Na polskim rynku z fabryki „Druh” pochodził tytoń sprzedawany pod nazwami „India” i „Turkos”. Dla palaczy fajek sprzedawano tytonie „Górniczy” i „Columbus”. Przeprowadzona w 1922 r. inspekcja dotycząca bezpieczeństwa pracy wykazała nieprawidłowości polegające na nieprzestrzeganiu instrukcji przeciwpożarowych, braku pomieszczeń dla pracowników, m.in. przebieralni i umywalni ${ }^{49}$. Firmę zamknięto w związku z utworzeniem Polskiego Monopolu Tytoniowego. 1 października 1924 r. Właściciel w miejscu fabryki papierosów uruchomił Fabrykę Drażetek, Masy Marcepanowej i Wyrobów Cukrowych „Lukullus”50.

Fabryka i Hurtownia Tytoniu Carla Blocha (Carl Bloch. Tabakfabrik \& Großhandelslager); Fabryka i Import Tytoniu Karola Blocha; adres obecny: ul. Unii Lubelskiej 4 (dawne adresy: Follerstrasse 2; ul. Unii Lubelskiej 2); właściciel: Karol (Carl) Bloch;

czas funkcjonowania: lata I wojny światowej - 1923/1924;

marka wiodąca: „Aksany” (dane z 1923 r.);

teren fabryki obecnie: zachowana zabudowa pofabryczna (funkcja usługowa, częściowo pustostan).

Właściciel fabryki Carl Bloch założył fabrykę w 1905 r. (nieznana lokalizacja, być może w Szubinie), którą w czasie pierwszej wojny światowej przeniósł do Bydgoszczy, zaś oddział otworzył w Gdańsku. Firma posiadała dwa okręty „Ernst” (600 ton) i „Vera” (400 ton) oraz 20 osób załogi. Tytoń kupowano na plantacjach amerykańskich, chińskich, indyjskich i hurtowo sprzedawano w Polsce, przede wszystkim na Pomorzu i w Wielkopolsce. K. Bloch oprócz hurtowni posiadał w Bydgoszczy fabrykę tytoniu. Na jej potrzeby zaadaptowano część pomieszczeń dawnego browaru, w którym zatrudniano 25 osób. Wyrabiano tytoń do papierosów i do fajek $^{51}$ (ryc. 8).

${ }^{48}$ Gilzy - puste bibułkowe tubki do samodzielnego wypełnienia tytoniem.

49 AP Bydgoszcz, AbmB, sygn. 5645.

${ }^{50}$ AP Bydgoszcz, AbmB, sygn. 5646.

${ }^{51}$ Quis. 1923a, s. 243-244. 


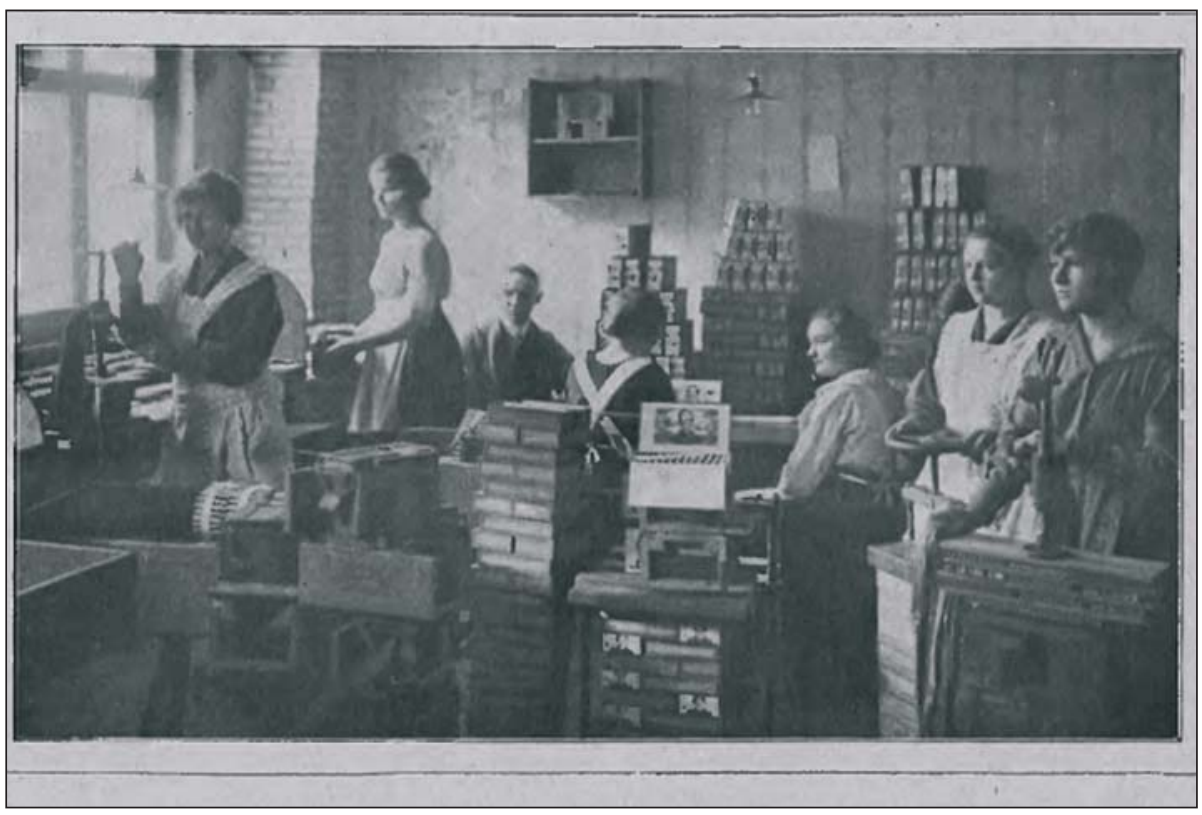

Ryc. 8. Oddział robotnic w fabryce tytoniu K. Blocha, fot. W. Wojucki (źródło: Quis. 123a, s. 243)

Fig. 8. A team of female workers in K. Bloch's tobacco factory, photo by W. Wojucki (source: Quis. 123a, p. 243)

\section{Fabryka Papierosów „Orient”;}

adres obecny: ul. Chrobrego 14 (dawne adresy: Schleinitzstrasse 20; ul. Chrobrego 20);

właściciele: Spółka Akcyjna w Poznaniu z siedzibą w Bydgoszczy;

czas funkcjonowania: 1919-1922;

marka wiodąca: „Palome” (dane z 1922 r.); teren fabryki obecnie: zabudowa nieistniejąca.

15 września 1919 r. kupcy Szmytkiewicz, Karasiński i Misterek zawiązali Spółkę Akcyjną „Orient” Towarzystwo Akcyjne w Poznaniu, z siedzibą w Bydgoszczy. Na potrzeby fabryki kupiono dawne kasyno oficerskie. Firma była notowana na Giełdzie Poznańskiej i zatrudniała ponad 100 pracowników. Najlepiej sprzedającym się produktem były papierosy „Palome” produkowane z mieszanki różnych tytoni ${ }^{52}$. W $1921 \mathrm{r}$. produkowano

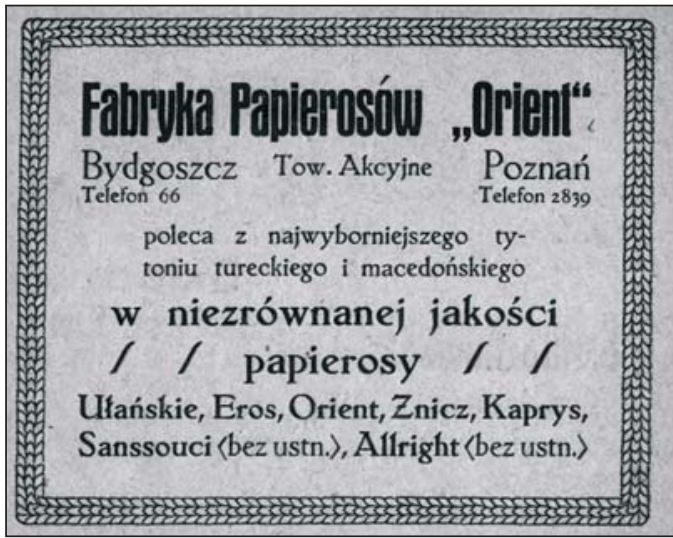

Ryc. 9. Reklama Fabryki Papierosów „Orient” (źródło: Łabendziński S. 1920, s. 8)

Fig. 9. Advertisement of the "Orient" Cigarette Factory (Fabryka Papierosów "Orient") (source: Łabendziński S. 1920, p. 8)

\footnotetext{
52 Fabryka. 1922, s. 6.
} 
2 miliony papierosów dziennie ${ }^{53}$, w tym: „Allright”, „SansSouci”, „Ułańskie”, „Damskie”, „Eros”, „Orient” i „Kaprys” ${ }^{4}$ (ryc. 9). Zakład uległ likwidacji w związku z utworzeniem Polskiego Monopolu Tytoniowego. Nieruchomość w 1925 r. przejęła Bydgoska Fabryka Makaronu i Środków Spożywczych „Kometa” założona przez Józefa Häuslera ${ }^{55}$.

\section{Polska Fabryka Tytoniu Juliana Króla;}

adres obecny: ul. Długa 63 (dawny adres: ul. Szpitalna 3 - wschodni fragment obecnej ul. Długiej, dołączony do niej po regulacji ulic na początku lat trzydziestych XX w.) (ryc. 10);

właściciel: Jan Król;

czas funkcjonowania: 1920-1922;

wiodące marki: „Legionka” i „Baśka” (dane z 1923 r.);

teren fabryki obecnie: zachowana zabudowa pofabryczna (funkcja mieszkalno-usługowo-biurowa).

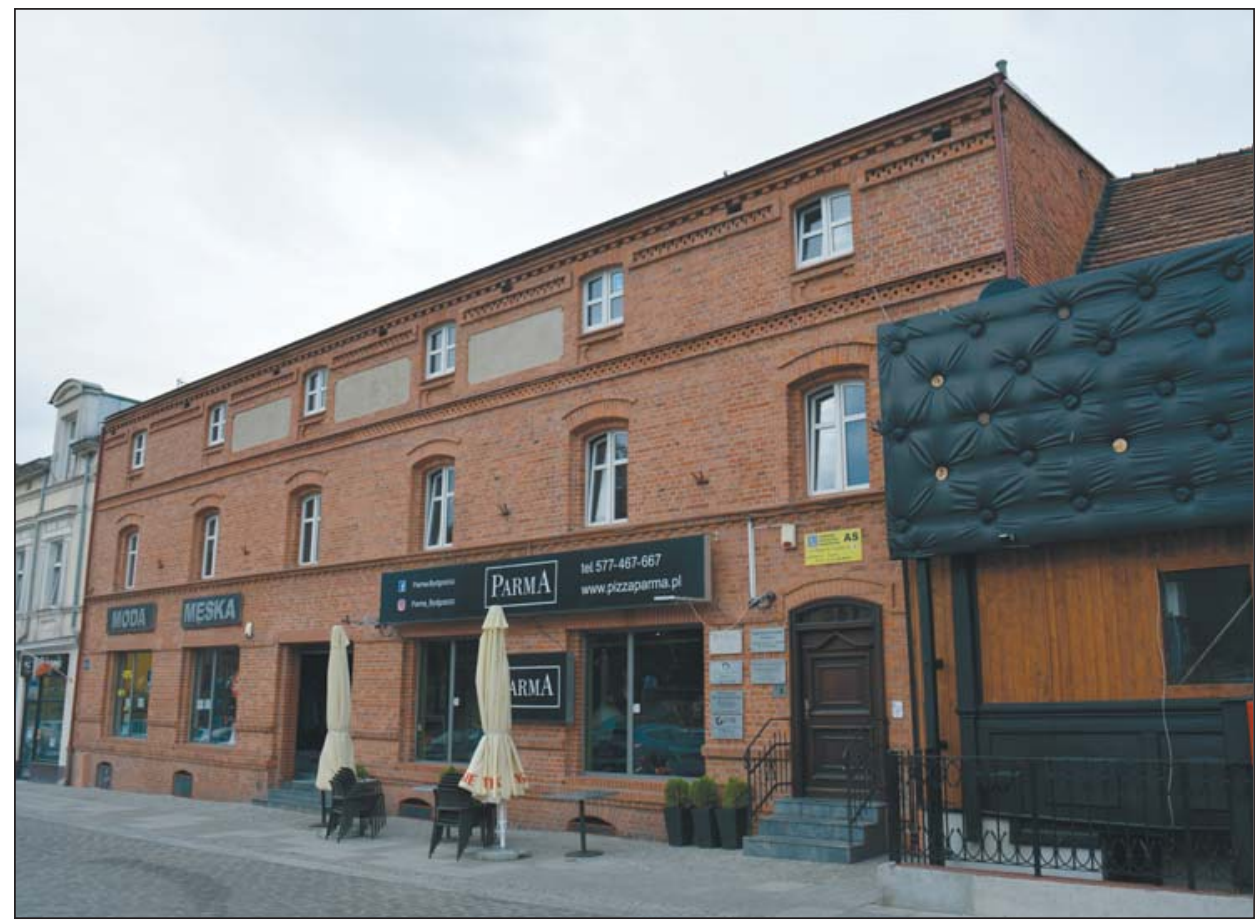

Ryc. 10. Zabudowa pofabryczna dawnej Polskiej Fabryki Tytoniu Juliana Króla przy obecnej ul. Długiej 63 (fot. A. Wysocka, 2021 r.)

Fig. 10. Former factory buildings of Julian Król's Polish Tobacco Factory (Polska Fabryka Tytoniu Juliana Króla) located at present-day 63 Długa St. (photo by A. Wysocka, 2021)

Na potrzeby fabryki zaadaptowano obiekty po dawnym browarze. Bydgoska firma była filią gdańskiej Fabryki Tytoniu. Jej właściciel Julian Król krótko przed pierwszą wojną światową założył fabrykę tytoniu w Berlinie i zbił majątek na dostawach tytoniu dla armii niemiec-

53 Anons. 1921b, s. 10.

54 Anons. 1921a, s. 3.

55 AP Bydgoszcz, AbmB, sygn. 3402. 
Ryc. 11. Reklama Polskiej Fabryki Tytoniu Juliana Króla

(źródło: Anons. 1921c, s. 5)

Fig. 11. Advertisement of Julian Król's Polish Tobacco Factory (Polska Fabryka Tytoniu Juliana Króla) (source: Anons. 1921c, p. 5)

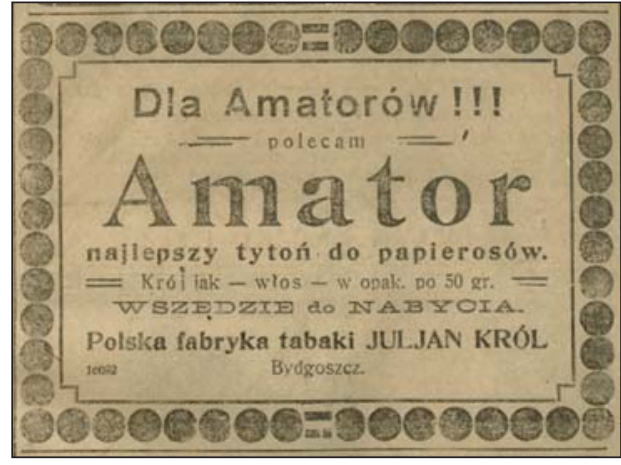

kiej. Po 1918 r. przeniósł ją do Gdańska-Wrzeszcza, dwa lata później otworzył oddział w Szubinie i w Bydgoszczy. Oprócz najpopularniejszych marek produkowano tytoń pod nazwami „Amator”, „Schag” i „Pola”, 56 (ryc. 11).

\section{Fabryka Tytoniu i Papierosów „Stambul” w Bydgoszczy;}

adres obecny: ul. Grunwaldzka 2-4 (dawny adres: ul. Jackowskiego 1/ul. Św. Trójcy 20-21); właściciel: Józef Robein;

czas funkcjonowania: 1920-1923/1924;

marka wiodąca: machorka „Cheval de bataille” (dane z 1923 r.);

teren fabryki obecnie: zabudowa nieistniejąca.

Fabryka powstała w lipcu 1920 r. z inicjatywy Józefa Robeina, który do Bydgoszczy przyjechał z Berlina. Zatrudniała 75 pracowników i dziennie przerabiała $1000 \mathrm{~kg}$ tytoniu. Surowiec sprowadzano z Turcji, Jawy i Ameryki Południowej. Flagowym produktem firmy była machor$\mathrm{ka}^{57}$ „Cheval de bataille”. Produkowano też tytonie „Kawalerski” i „Egipski” ${ }^{58}$.

Fabryka wyrobów Tytoniowych i Gilz, „Pomorze". Skrzynecki, Kossakowski i Spółka w Bydgoszczy;

adres obecny: ul. Garbary 17 (dawny adres: ul. Garbary 10);

właściciele: Roman Skrzynecki, Stefan Kossakowski;

czas funkcjonowania: 1921-1923/1924;

marka wiodąca: papierosy „Pomorze” (dane z 1923 r.);

teren fabryki obecnie: częściowo zachowana zabudowa pofabryczna (funkcja gospodarcza).

Założona w 1921 r. fabryka swoją pierwszą siedzibę miała przy ul. Cieszkowskiego, $\mathrm{w}$ tym samym roku przeniesiona została do

56 Cajus. 1923a, s. 174-175.

57 Machorka - suszone liście gorszego gatunku tytoniu bakun, zawierające 9\% nikotyny, czyli 3-10 razy więcej niż tytonie szlachetne, np. Virginia.

58 Stambuł. 1923, s. 179.

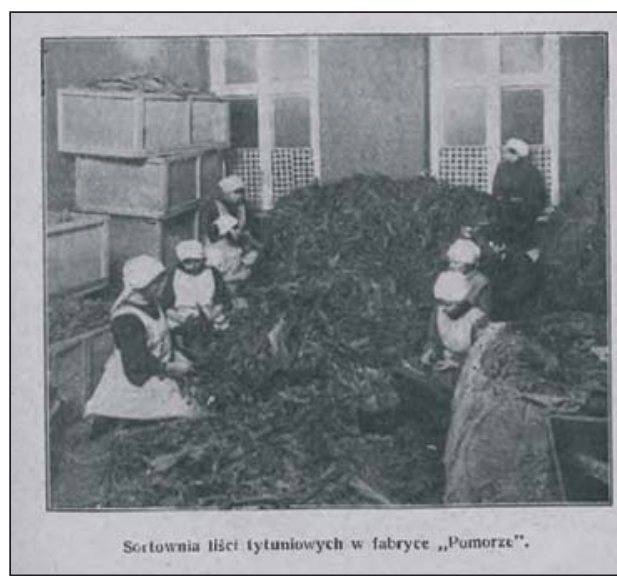

Ryc. 12. Sortownia liści tytoniowych w fabryce „Pomorze”, fot. W. Wojucki (źródło: Fortis. 1923, s. 241)

Fig. 12. Tobacco leaf sorting facility at the "Pomorze" factory, photo by W. Wojucki (source: Fortis. 1923, p. 241) 
pomieszczeń przy ul. Garbary 17. Jej właścicielem był Roman Skrzynecki, były wojskowy, do którego dołączył Stefan Kossakowski, również były wojskowy. Zakład zatrudniał 100 robotnic, co podkreślano „[Właściciele - A.W.] specjalnie w tej mierze dają baczenie, iżby zatrudniać w pierwszym rzędzie wdowy i córki, pozostałe po poległych towarzyszach broni" ${ }^{59}$ (ryc. 12). Fabryka składała się z hali maszyn, krajalni tytoniu, sortowni, oddziału pakowania papierosów, własnej drukarni i introligatorni oraz oddziału ekspedycji. Tytoń sprowadzano z Bułgarii, Grecji i Turcji, a bibułki do papierosów z Francji. Fabryka, oprócz marki wiodącej, produkowała papierosy o nazwach: „Arkadia”, „Osman”, „Boston” oraz „York”60.

Fabryka Skrzynek do Cygar (Zigarrenkistenfabriken);

adres obecny: ul. Toruńska 89 (dawniej przedmieście Małe Bartodzieje — Klein-Bartelsee);

właściciel: Carl Schröder;

czas funkcjonowania: 1902-1939;

teren fabryki obecnie: zabudowa nieistniejąca.

Funkcjonująca od 1902 r. Fabryka Skrzynek do Cygar Carla Schrödera była filią macierzystej placówki powstałej w 1842 r. w Magdeburgu. Wielokrotnie przekształcana i zmieniająca właścicieli wytwórnia przetrwała do końca lat trzydziestych XX w., gdy kupili ją potentaci meblowi na rynku bydgoskim — rodzina Pfefferkorn. Stała się wówczas częścią „Fabryki Mebli Wyściełanych Ottona i Karola Pffeferkornów"61.

Oprócz wymienionych w artykule fabryk istniały też inne. Ich trwanie, według „Ksiąg Adresowych miasta Bydgoszczy" było kilkuletnie, a przygotowywane w kolejnych latach tomy nie zawsze odnotowują ich aktywność. Jeśli w dokumentacji przechowywanej w Archiwum Państwowym w Bydgoszczy zarejestrowano tylko nazwę firmy i daty funkcjonowania, również nie znalazły się one w niniejszym opracowaniu. Nie znaczy to, że nie warto prześledzić działalności tych wytwórni. Jednakże na obecnym, wstępnym etapie rozpoznania tematu, nie wydawało się zasadne ich uwzględnianie.

Fabryki i opis ich działalności umożliwiają wysunięcie kilku wniosków. Bydgoskie firmy wyrobów tytoniowych powstawały po połowie XIX w., gdy kryzys w rozwoju miasta z końca XVIII w. został w pełni opanowany. Osiągnięta stabilizacja stała się podstawą dla rozbudowy miasta dzięki rozwojowi gospodarczemu. Miały w tym udział fabryki, w których przerabiano tytoń, produkowano cygara i papierosy, a często ich produkcję łączono. Dynamika ich rozwoju była znaczna, skoro część posiadała filie zamiejscowe. Problemem było znalezienie pracowników. Robotnicy zatrudnieni bezpośrednio przy produkcji zarabiali mniej niż w innych gałęziach przemysłu, stąd pomysły na kursy dokształcające i zatrudnianie kobiet, pracujących za niższe stawki niż mężczyźni. W 1907 r. dwie bydgoskie fabryki cygar i dwie fabryki tytoniowe zatrudniały 250 robotnic ${ }^{62}$. Rozwój zakładów wyhamował w czasie pierwszej wojny światowej, na co wpływ miał przede wszystkim brak surowca i niepewność w związku ze zmianą granic. Właściciele w większości likwidowali bydgoskie przedsiębiorstwa przenosząc się na tereny Niemiec, nie czekając na ostateczne, polityczne rozwiązania kwestii przebiegu granic. Przemysł tytoniowy w Bydgoszczy szybko się odrodził, tym razem jako przemysł polski. Szczególną intensywność, jeżeli chodzi o powstawanie krótko działających zakładów o opisywanym profilu, zauważyć można w okresie scalania państwa polskiego. Wskazują na to pojawiające się anonse w „Dzienniku Bydgoskim” z lat 1918-1920. Zakładanie fabryk ułatwiał nie do końca precy-

\footnotetext{
59 Fortis. 1923, s. 241; AP Bydgoszcz, ARH, sygn. 869.

${ }^{60}$ Fortis. 1923, s. 242.

${ }^{61}$ Derkowska-Kostkowska B. 2018, s. 135-136.

62 Tabakindustrie. 1907, s. 246.
} 
zyjny, dopiero co wypracowywany i utrwalany polski prawny porządek gospodarczy. Na bazie istniejącej infrastruktury związanej z przemysłem wyrobów tytoniowych w $1922 \mathrm{r}$. zdecydowano o otwarciu w mieście jednej z 18 fabryk należących w czasach drugiej Rzeczypospolitej do Polskiego Monopolu Tytoniowego.

Artykuł nie wyczerpuje tematu, lecz stanowi punkt wyjścia do badań kolejnych, naszkicowanych tu wątków: struktury zatrudnienia, sprzedaży hurtowej i detalicznej, architektury kompleksów pofabrycznych. Równie interesujące wydają się aspekty związane z kulturą palenia w XIX i na początku XX w. w Bydgoszczy. W tej kwestii warto m.in. przeanalizować nazwy produkowanych tutaj wyrobów tytoniowych. Stworzona na potrzeby artykułu historyczna topografia wpisuje w poindustrialne dziedzictwo miasta rozdział o przemyśle tytoniowym.

Adres Autorki:

dr Agnieszka Wysocka

Uniwersytet Kazimierza Wielkiego w Bydgoszczy

ul. J.K. Chodkiewicza 30

85-064 Bydgoszcz

agawyso@ukw.edu.pl

https://orcid.org/0000-0002-9795-952X

\section{BIBLIOGRAFIA}

\section{Źródla archiwalne}

AP Bydgoszcz [Archiwum Państwowe w Bydgoszczy], ARH [Akta Rejestru Handlowego], Blatsammlung betreffend die Firma Russiche Cigaretten Fabrik Bessarabia, Inhaber Joseph von Pawłowski, sygn. M 31.

AP Bydgoszcz [Archiwum Państwowe w Bydgoszczy], ARH [Akta Rejestru Handlowego], Bydgoska Fabryka Cygar [później] Ubrań, Towarzystwo Akcyjne, sygn. 807.

AP Bydgoszcz [Archiwum Państwowe w Bydgoszczy], ARH [Akta Rejestru Handlowego], „Pomorze”. Skrzynecki, Kossakowski i S-ka. Fabryka Papierosów i Gilz. Towarzystwo z ograniczoną odpowiedzialnością w Bydgoszczy, sygn. 869.

AP Bydgoszcz [Archiwum Państwowe w Bydgoszczy], ARH [Akta Rejestru Handlowego], Firma L.(Leopold) Landsberger [Fabryka cygar, ul. Łokietka 8b], sygn. 3730.

AP Bydgoszcz [Archiwum Państwowe w Bydgoszczy], AbmB [Akta budowlane miasta Bydgoszczy], sygn. 54; sygn. 69, sygn. 3402; sygn. 3959-3960, sygn. 5645-5647.

AP Bydgoszcz [Archiwum Państwowe w Bydgoszczy], AmB [Akta miasta Bydgoszczy], sygn. 47.

\section{Źródła i opracowania publikowane}

75-lecie. 1923. 75-lecie najstarszej fabryki cygar w Polsce, „Tygodnik Ilustrowany”, nr 11, 10 marca, s. 176-178.

Adama Cygara. 1923. Adama Cygara Bydgoskie, „Tygodnik Ilustrowany”, nr 29, 14 lipca, s. $472-$ -475 .

Anons. 1908a. Anons reklamowy, „Dziennik Bydgoski”, nr 130, 7 czerwca, s. 4.

Anons. 1908b. Anons reklamowy, „Dziennik Bydgoski”, nr 288, 17 grudnia, s. 4.

Anons. 1909. Anons reklamowy, „Dziennik Bydgoski”, nr 92, 23 marca, s. 4.

Anons. 1910. Anons reklamowy, „Dziennik Bydgoski”, nr 110, 3 lipca, s. 4.

Anons. 1916. Anons reklamowy, „Dziennik Bydgoski”, nr 22, 28 stycznia, s. 4.

Anons. 1921a. Anons reklamowy, „Dziennik Bydgoski”, nr 38, 17 luty, s. 3.

Anons. 1921b. Anons reklamowy, „Dziennik Bydgoski”, nr 120, 29 maja, s. 10.

Anons. 1921c. Anons reklamowy, „Dziennik Bydgoski”, nr 210, 14 września, s. 5.

Cajus. 1923a. „Legionka”, „Tygodnik Ilustrowany”, nr 11, 10 marca, s. 174-175.

Cajus. 1923b. Bydgoska Fabryka Cygar Tow. Akc. w Bydgoszczy, „Tygodnik Ilustrowany”, nr 11, 10 marca, s. 192. 
Derkowska-Kostkowska Bogna. 2018. Retro-przewodnik — od warsztatu do fabryki, Bydgoszcz.

Fabryka. 1920. Fabryka Adama, „Dziennik Bydgoski”, nr 207, 17 września, s. 2.

Fabryka. 1922. Fabryka papierosów „,Orient”, „Gazeta Bydgoska”, nr 28, 3 sierpnia, s. 6.

Ferland Catherine. 2007. Mémoires tabagiques. L'usage du tabac, du XVe siecle a nos jours. „Drogues, santé et société", t. 6, nr 1, s. 17-48, https://doi.org./10.7202/016942ar (dostęp 28.09.2021).

Fiedler L.K. 1923. Przemyst Wielkopolski, Poznań.

Fortis. 1923. Fabryka wyrobów Tytuniowych „Pomorze” w Bydgoszczy, Garbary 10, „Tygodnik Ilustrowany", nr 15, 7 kwietnia, s. 241-242.

Głowacka Iwona. 2020. Otoczenie regulacyjne upraw i produkcji tytoniu w Polsce oraz znaczenie sektora tytoniowego dla gospodarki krajowej, Warszawa.

Jastrzębska-Puzowska Iwona. 2005. Od miasteczka do metropolii. Rozwój architektoniczny i urbanistyczny Bydgoszczy w latach 1850-1920, Toruń.

Jeleniewski Marek. K. 2009. Bydgoski Przemyst Tytoniowy w czasach Drugiej Rzeczypospolitej, „Kronika Bydgoska”, t. XXX, s. 111-122.

Kaliszczuk M. 1981. Hasło: Polski Monopol Tytoniowy, [w:] Encyklopedia Gospodarcza Polski do 1945 roku, t. II, red. A. Mączak, Warszawa, s. 108-109.

Katalog wystawy. 1929. Polski Monopol Tytoniowy jako pracodawca, bmw.

Księga adresowa. 1855. Wohnungs-Anzeiger nebst Adress-und Geschäfts-Handbuch für Bromberg und Umgebung auf das Jahr 1855, Bromberg.

Łabendziński S. 1920. Ilustrowany przewodnik po Bydgoszczy i dalszej okolicy, Bydgoszcz, s. 8.

Marcinek Roman. 2012. Stawne ziele zwane tabaka, Wilanów.

Mincer Franciszek. 1991. Przemiany administracyjne i społeczno-gospodarcze w pierwszym okresie rzadów pruskich (1772-1806), [w:] Historia Bydgoszczy, t. 1: do 1920 roku, red. M. Biskup, Warszawa-Poznań, s. 341-393.

Ogłoszenie. 1909. Ogłoszenie, „Dziennik Bydgoski”, nr 265, 24 listopada, s. 4.

Pawłowski Józef. 1908a. Hodowla tytoniu w Turcji, „Dziennik Bydgoski”, nr 230, 8 października, s. 2.

Pawłowski Józef. 1908b. O tytoniu, „Dziennik Bydgoski”, nr 231, 9 października, s. 2.

Pawłowski Józef. 1908c. O tytoniu, „Dziennik Bydgoski”, nr 232, 10 października, s. 2.

Pawłowski Józef. 1908d. O tytoniu, „Dziennik Bydgoski”, nr 233, 11 października, s. 2.

Quis. 1923a. Człowiek, który ma własne okręty i importuje niemi tytuń do Polski, „Tygodnik Ilustrowany", nr 11, 10 marca, s. 243-244.

Quis. 1923b. Fabryka tytuniu i papierosów „Druh” w Bydgoszczy, „Tygodnik Ilustrowany”, nr 12, 17 marca, s. 94-95.

Skulski Julian. 1920. Tytoń i jego uprawa, Kraków.

Smutna wiadomość. 1914. Smutna wiadomość, „Dziennik Bydgoski”, nr 27, 4 luty, s. 3.

Spis nagród. 1910. Spis nagród na wystawie Przemysłowej w Bydgoszczy, „Dziennik Bydgoski”, nr 156, 14 lipca, s. 2.

Stambuł. 1923. ,, Stambul” Fabryka tytuniu i papierosów w Bydgoszczy, ul. Jackowskiego 1, „Tygodnik Ilustrowany", nr 11, 10 marca, s. 179.

Tabakindustrie. 1907. Tabakindustrie, [w:] Industrie und Gewerbe in Bromberg, red. B. Böhm, Bromberg, s. 245-248.

Uprawa. 1926. Uprawa tytoniu w Polsce w świetle cyfr, Warszawa.

Wajda Kazimierz. 1991. Przeobrażenia gospodarcze Bydgoszczy w latach 1850-1914, [w:] Historia Bydgoszczy, red. M. Biskup, t. 1: do 1920 roku, Warszawa-Poznań, s. 530-541.

Wysocka Agnieszka. 2016. Architektura bydgoskiego Monopolu Tytoniowego, [w:] Jedza, pija, lulki palą. Kulturowe aspekty korzystania z używek na przestrzeni dziejów, t. II: Antropologia używek w gospodarce i życiu społecznym, red. J. Żychlińska, A. Głowacka-Penczyńska, J. Woźny, Bydgoszcz, s. 47-56.

Zwiedzanie. 1913. Zwiedzanie fabryki, „Dziennik Bydgoski”, nr 185, 13 sierpnia, s. 2-3. 
Tobacco factories in Bydgoszcz

in the second half of the 19th century until the establishment

of the Polish Tobacco Monopoly in 1922

The tobacco industry played an important role in the history of industry in Bydgoszcz in the 19th and early 20th centuries. Large factories (Adam's Cigar Factory (Adam's Zigarrenfabrik), Norbert Beume's Cigar Factory (Fabryka Cygar Norberta Beume) and smaller ones (Carl Bloch's Tobacco Factory and Wholesale (Fabryka i Hurtownia Tytoniu Carla Blocha) were established. Their owners took advantage of the good economic situation (supplies for the army, the growing popularity of smoking tobacco) and the ease of establishing companies. In the Prussian partition, as in the whole of Germany, there was no monopoly on tobacco products. Factory owners and wholesalers paid high taxes, but production was profitable. Factories in Bydgoszcz produced cigars and cigarettes and prepared tobacco for smoking, and the times - Poland regaining its independence and consolidating the statehood (1918-1920) — were favourable for the creation of new factories in this sector. The private tobacco industry developed in Bydgoszcz (as in the whole country) until 1924 when the Polish state introduced a monopoly on tobacco products to fully control its functioning.

This article reconstructs the history of selected factories and identifies places in the modern townscape where factories and warehouses related to the tobacco industry were located before 1924, demonstrating that the tobacco industry, among others, was an important element of the local industrial tradition. In Bydgoszcz in 1924, the Adam's Cigar Factory (Adam's Zigarrenfabrik), the tradition of which dated back to 1878 , became the basis for the establishment of a factory belonging to the Polish Tobacco Monopoly.

Translated by Karolina Płoska

Proofread by Rebecca Gorzynska 